Nat. Hazards Earth Syst. Sci. Discuss., https://doi.org/10.5194/nhess-2018-18

Manuscript under review for journal Nat. Hazards Earth Syst. Sci.

Discussion started: 30 January 2018

(c) Author(s) 2018. CC BY 4.0 License.
Natural Hazards

and Earth System

Sciences

Discussions

(c) (i)

\title{
Global warming causes sinkhole collapse - Case study in Florida, USA
}

Yan Meng ${ }^{1,2, *}$, Long $\mathrm{Jia}^{2}$

${ }^{1}$ School of environmental studies, China university of Geosciences, Wuhan, 430074, China

$5{ }^{2}$ Institute of Karst Geology, Chinese Academy of Geological Sciences/Karst Dynamics Laboratory, MLR \& GZAR, CGS, Guilin, 541004, China

Correspondence to: Yan Meng (sinkhole@163.com)

Abstract. The occurrence frequency and intensity of many natural geohazards, such as landslides, debris flows and earthquakes, have increased in response to global warming. However, the effects of such on development and spread of

10 sinkholes has been largely overlooked. Most research shows that water pumping and related drawdown is the most important factor in sinkhole development, but in this paper evidence is presented which highlights the role played by global warming in causing sinkholes. The state of Florida, USA is used as a case study in which the role of global warming is evident, based on correlation analysis between sinkhole collapse and peak drought periods. Three distinct drought and sinkhole collapse phases are evident between 1965 and 2006, along with eight peak periods of sinkhole collapse that lag slightly behind eight peak

15 drought periods. A prediction equation is derived according to curve fitting and a correlation coefficient of 0.999 is determined. The results of this study confirm that global warming related to climate change has led to an increase in sinkhole collapse events in Florida over the past 50 years, which is of significance for studying the occurrence and prediction of other sinkhole collapse events and global warming on an international scale.

\section{Keywords}

Geohazard; Drought; Karst; Trend prediction; Curve fitting

\section{Introduction}

Global warming resulting from climate change has altered the occurrence frequency and intensity of many natural geohazards, including landslides, debris flows and earthquakes (Calbó et al., 2010; Coe and Godt., 2012; Seneviratne et al., 2012; Gariano and Guzzetti., 2016; Heuvel, et al., 2016; Turkington, et al., 2016; Yongming Lin, et al., 2017). As an

25 example of the mechanism for this, research has shown that 5\%-10\% of global permafrost will melt if global temperatures rise by $2^{\circ} \mathrm{C}$, causing a significant increase in landslides and mudslides (Dong and Jia., 2004).

Sinkholes are a widespread type of geohazard, mainly distributed in the United States, China, Italy, Spain and Russia (Gutiérrez, et al., 2014; Lei, et al., 2015). The impact of climate change on sinkhole occurrence is expected, because rising temperatures will change natural hydrological processes (Gabriella Szépszó, et al., 2014), enhance dissolution of limestone

30 (Mulec and Prelovšek., 2014) and promote soil failure (Zhou, et al., 2014). Recent reviews in the literature have shown that 
Nat. Hazards Earth Syst. Sci. Discuss., https://doi.org/10.5194/nhess-2018-18

Manuscript under review for journal Nat. Hazards Earth Syst. Sci.

Discussion started: 30 January 2018

(c) Author(s) 2018. CC BY 4.0 License.

(c) (i)

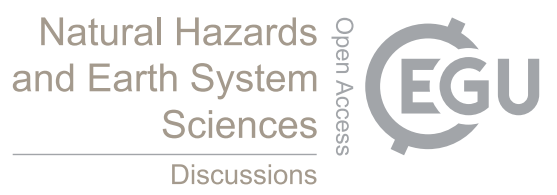

sinkhole hazards will probably intensify in the future as a result of climate change (Rogelio Linares, et al., 2017), but quantification of the impact on sinkholes has been limited. This is largely because of a lack of long-term hydrological and climate data, and a lack of representative sinkhole inventories, inclusive of chronological information.

In this paper, the causal effects of global warming on sinkhole development and intensification are fully investigated using

5 statistical analysis of sinkhole cases in the state of Florida, USA. In general, it can be shown that for every $0.1^{\circ} \mathrm{C}$ rise in global temperature, the number of sinkholes increases by $1 \%-3 \%$.

\section{Materials and methods}

\subsection{Global temperature}

Global warming as a result of climate change is a quantifiable phenomenon (Shi et al., 2010; Gariano, et al., 2016;

10 Turkington, et al., 2016), with a demonstrable increase in global temperatures by $\sim 0.57^{\circ} \mathrm{C}$ over the last century (Fig. 1). It has been reported that the global surface temperature is likely to rise a further 0.3 to $1.7^{\circ} \mathrm{C}$ in the lowest emissions scenario during the 21 st century, or by 2.6 to $4.8^{\circ} \mathrm{C}$ in the highest emissions scenario (IPCC, 2013).

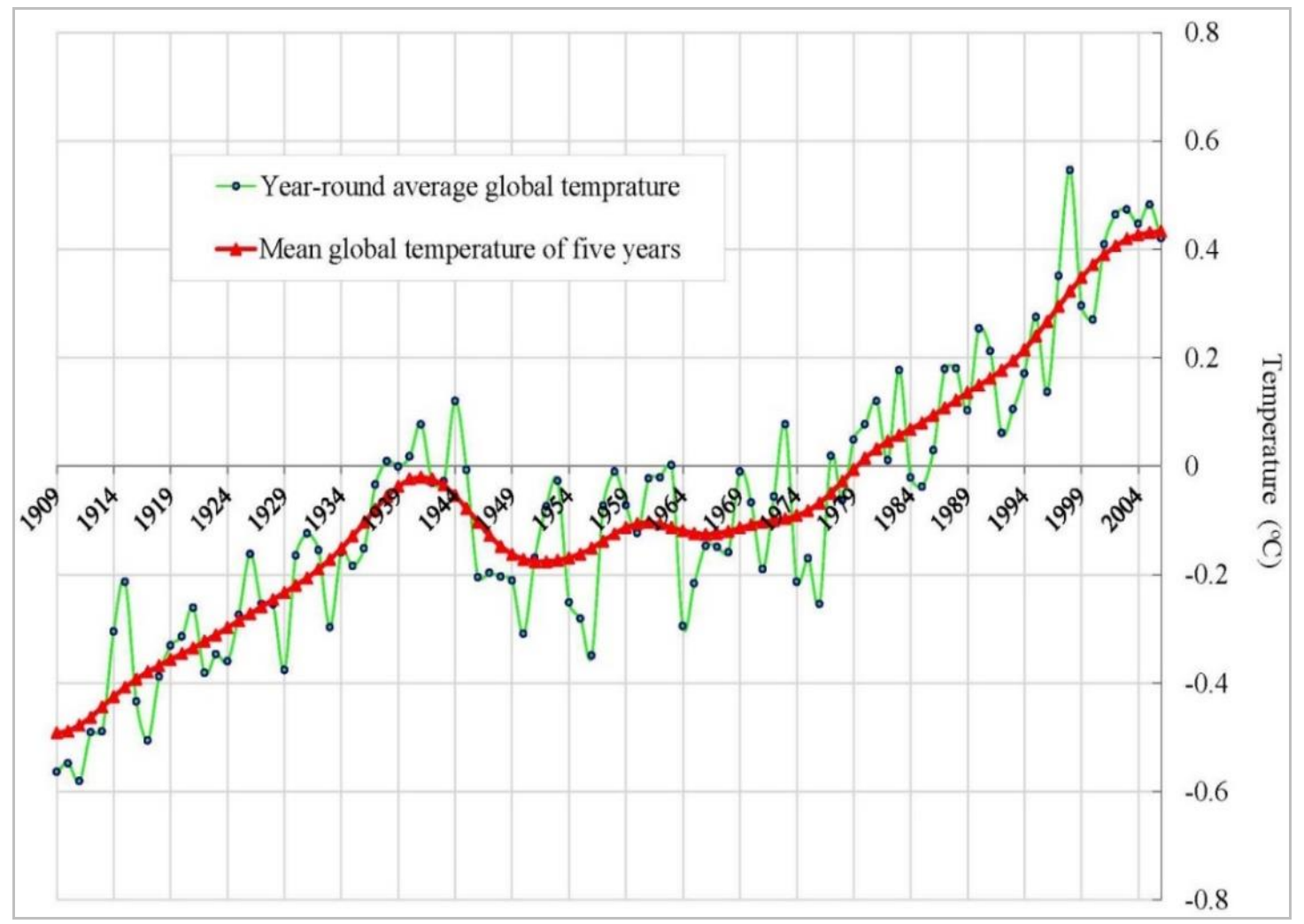

Figure 1: Global mean surface-temperature changes from 1909 to 2006. The green line is the global annual mean, and the red line 
Nat. Hazards Earth Syst. Sci. Discuss., https://doi.org/10.5194/nhess-2018-18

Manuscript under review for journal Nat. Hazards Earth Syst. Sci.

Discussion started: 30 January 2018

(c) Author(s) 2018. CC BY 4.0 License.
Natural Hazards

and Earth System

Sciences

Discussions

\subsection{Sinkhole collapse events in Florida}

In Florida, sinkhole collapse events are recorded in the Florida Subsidence Incident Report, authored by the Florida Geological Survey, which provides a primary publicly available sinkhole database. More than 2800 sinkholes have been reported in Florida since the 1950s, and 2786 of them were fully recorded between 1949 and 2006. The data recorded includes occurrence time, location, shape, dimensions, soil type, side slope, land use and land cover (Han, et al., 2016). The long-term and complete records of such sinkholes form the basis of the time peak relationship analysis between sinkhole collapse and global warming.

The sinkhole collapses recorded in Florida have three distinct peaks (Fig. 2) and provide ideal research candidates, which is why this region was chosen for the study. The study is based on the 2786 sinkholes that have been well-documented.

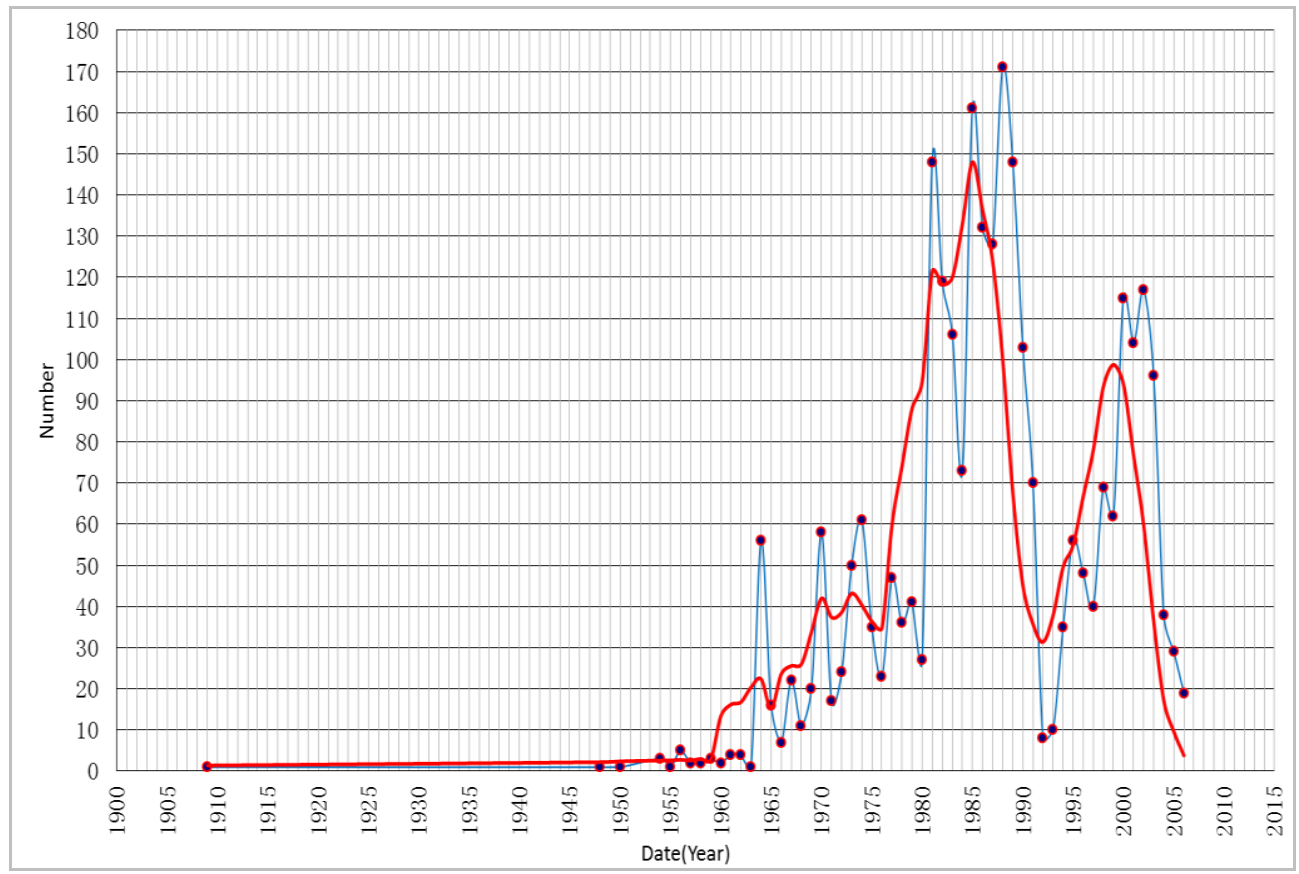

Figure 2: Frequency of sinkhole formation between 1948 and 2006 in Florida, USA. The red line is the five-year local regression line (data obtained from the Florida Office of Insurance Regulation).

Most research has shown that pumping of water and associated drawdown is the leading cause of sinkhole formation and collapse (Anikeev and Leonenko., 2014; Youssef, et al., 2016; Rogelio Linares, et al., 2017). However, the impact of global warming should not be ignored. For example, altered global rainfall patterns and increasing evaporation because of higher temperatures leads to a decrease in groundwater flow, resulting in sinkhole formation, or such decreased flow may lead to intensification of water pumping and related drawdown in urban and industrial areas that in itself leads to groundwater level reduction and related sinkhole development.

Also, the addition of greenhouse gases to the atmosphere and global warming increase the dissolution of bedrock, thus increasing the intensity and frequency of sinkhole collapse. This is especially true for areas underlain by limestone or 
Nat. Hazards Earth Syst. Sci. Discuss., https://doi.org/10.5194/nhess-2018-18

Manuscript under review for journal Nat. Hazards Earth Syst. Sci.

Discussion started: 30 January 2018

(c) Author(s) 2018. CC BY 4.0 License.

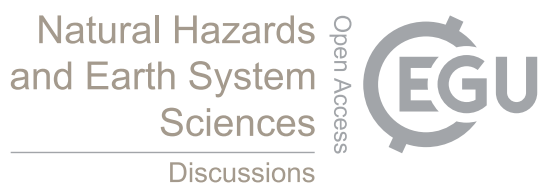

(c) (1)

dolomite, in which the basic carbonate dissolution formula $\mathrm{CaCO}_{3}+2 \mathrm{H}^{+} \rightarrow \mathrm{Ca}^{2+}+\mathrm{H}_{2} \mathrm{O}+\mathrm{CO}_{2}$ shows the breakdown of solid carbonates in acidic conditions. The carbonate dissolution formula is reversible, but will proceed in the positive direction as temperatures increase. In susceptible areas, some closed or previously blocked karst pipes or cracks will open up under conditions of dissolution, and form new soil erosion channels. Dehydration of the soil will occur as the temperature increases, and once runoff occurs or water levels rise, the dry soil will be removed, leading to erosion and disintegration as the sinkhole forms and collapses.

\subsection{Correlation analysis}

\subsubsection{Sinkhole and drought peaks}

Droughts in the USA can be divided into three basic, consistent peak periods: Phase i between 1965 and 1973, Phase ii between 1973 and 1991 and Phase iii between 1991 and 2006. Sinkhole collapses in the USA can also be divided into three basic consistent peak periods: Phase i between 1968 and 1980, Phase ii between 1980 and 1993 and Phase iii between 1993 and 2006. From Fig. 3 it is evident that the peak time and trend of sinkhole collapse events and drought periods are quite consistent. To further investigate the relationship, the association can be quantified using curve fitting analysis.

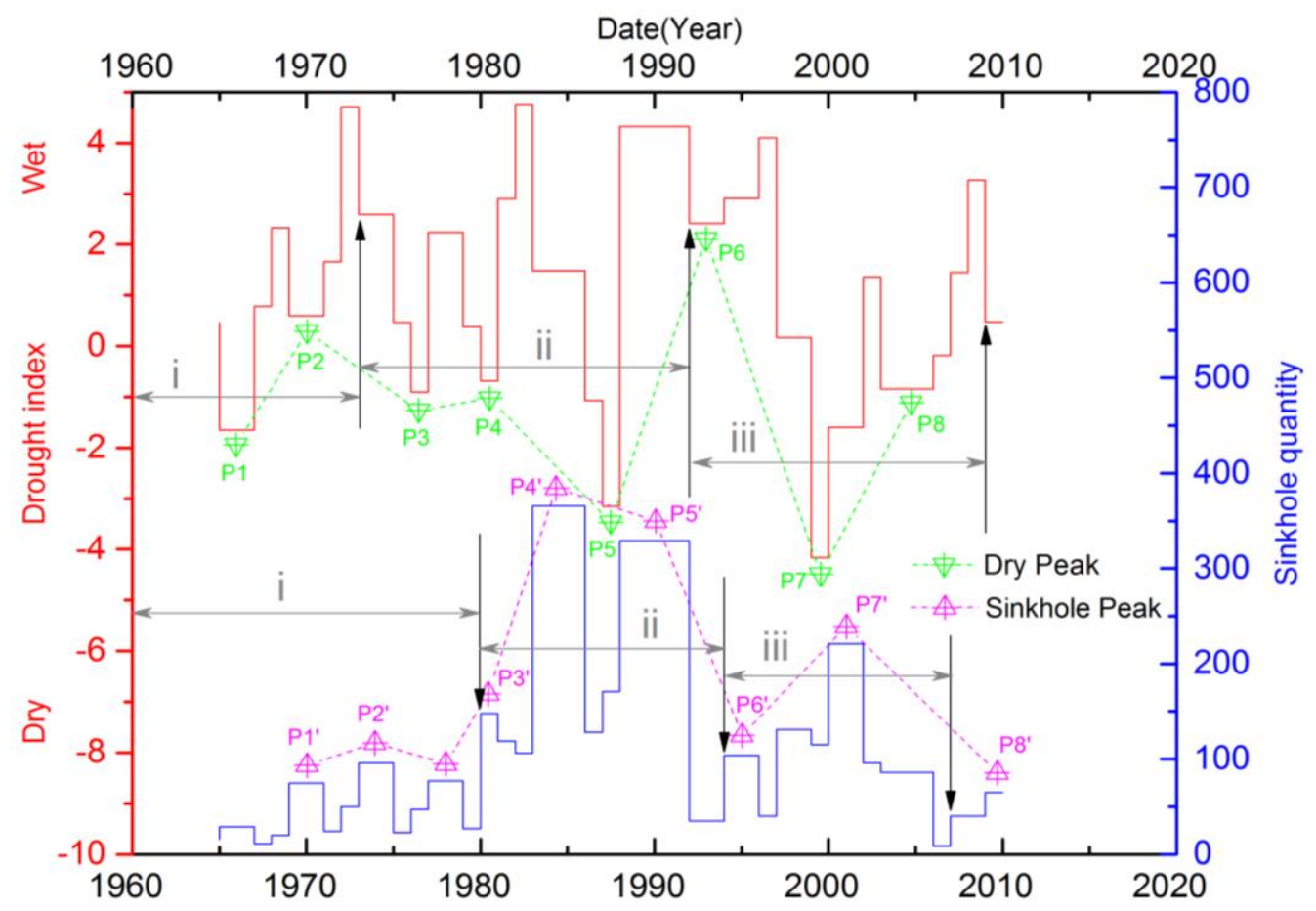

15 Figure 3: Graphical illustration of the relationship between sinkhole quantity (blue) and drought periods (red) in Florida, USA. Note the eight peak "dry" and "sinkhole" periods shown (P1-P8) and the three corresponding phases (i, ii, iii) of highly consistent trends in sinkhole development and drought. 
Nat. Hazards Earth Syst. Sci. Discuss., https://doi.org/10.5194/nhess-2018-18

Manuscript under review for journal Nat. Hazards Earth Syst. Sci.

Discussion started: 30 January 2018

(c) Author(s) 2018. CC BY 4.0 License.

\section{(c) (i)}

\subsubsection{Curve fitting}

The curve of sinkhole collapse quantity and drought index can be fitted, as shown in Fig. 4, by Eq. (1).

$$
\sqrt{\left((X-B)^{2}+(Y-A)^{2}\right.}-R=0
$$

The algorithm is derived using the Quasi-Newton (Broyden Fletcher Goldfard Shanno (BFGS) and Universal Global(UG))

5 methods, where $\mathrm{X}$ is the drought index, $\mathrm{Y}$ is the number of sinkhole collapses and $\mathrm{A}, \mathrm{B}$ and $\mathrm{R}$ are constant parameters. The correlation coefficient is 0.999 . The other parameters are shown in Table 1.

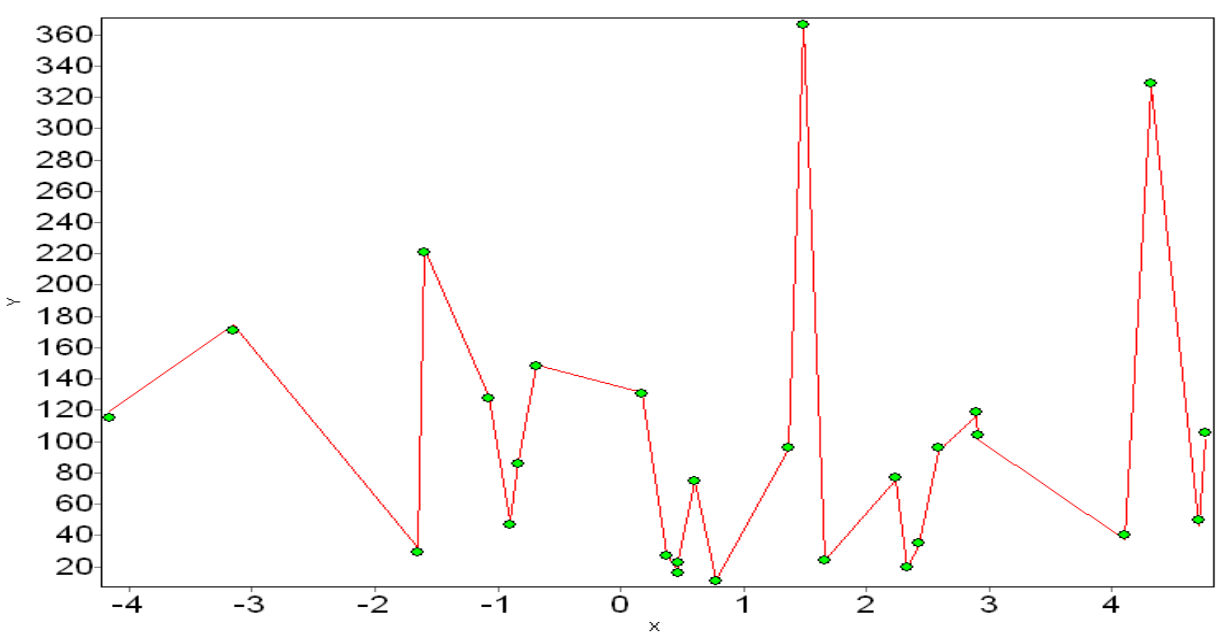

Figure4: Fitted curves of sinkhole collapse quantity and drought index.

Table 1: Algorithm and parameters of the drought time curve.

\begin{tabular}{|c|c|c|}
\hline Equation & & $\operatorname{Sqrt}\left((\mathrm{X}-\mathrm{B})^{\wedge} 2+(\mathrm{Y}-\mathrm{A})^{\wedge} 2\right)-\mathrm{R}=0$ \\
\hline \multirow{9}{*}{$\begin{array}{l}\text { Algorithm and } \\
\text { parameters }\end{array}$} & A 173.499 & $\begin{array}{l}\text { Optimization: Quasi-Newton Method(BFGS) + Universal } \\
\text { Global }\end{array}$ \\
\hline & В 8100.396 & Calculation End: Meet convergence criteria \\
\hline & $\begin{array}{ll}\mathrm{R} & 8100.217\end{array}$ & Mean square error(RMSE): 2.17562755356349 \\
\hline & & Residual sum of squares (SSE): 127.800591799266 \\
\hline & & Correlation coefficient(R): 0.999689237322014 \\
\hline & & $\begin{array}{l}\text { The square of Correlation coefficient }\left(\mathrm{R}^{\wedge} 2\right) \text { : } \\
0.99937857121747\end{array}$ \\
\hline & & Determine the coefficient(DC): 0.999378190981562 \\
\hline & & Chi-Square coefficient: 0.958830651014433 \\
\hline & & F-Statistic: 40204.8713912301 \\
\hline
\end{tabular}


Nat. Hazards Earth Syst. Sci. Discuss., https://doi.org/10.5194/nhess-2018-18

Manuscript under review for journal Nat. Hazards Earth Syst. Sci.

Discussion started: 30 January 2018

(c) Author(s) 2018. CC BY 4.0 License.

(c) (i)

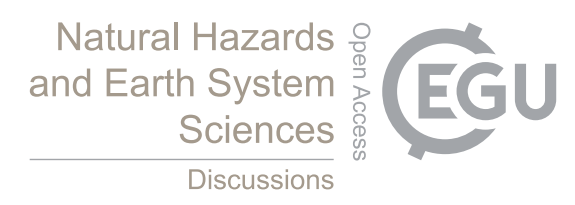

\section{Conclusions}

There is a strong corresponding relationship between sinkhole quantity and drought index shown in Fig. 3, which demonstrates the link between global warming and increased development of sinkhole collapse events in Florida, USA. Eight peak points (P1-P8) within three peak drought periods correspond to sinkhole peak periods (P1'-P8'). The timing of

5 sinkhole formation lags behind the drought by two to four years, which is geologically sensible, given that water pumping and drawdown, along with soil runoff caused by rain, will take some time after the onset of drought before the sinkhole opens.

This is significant for use by government disaster reduction departments, or insurers, who may require forward-modeling of likely future events, such as sinkhole collapse following periods of drought. This will allow for controls of sinkhole collapse

10 to be established and to develop monitoring networks.

To clearly define the quantitative relationship between sinkhole collapse and drought, a curve fitting method was applied based on the optimization of Quasi-Newton (BFGS) and Universal Global methods. A prediction equation (Eq. 1) was also obtained according to the curve fitting.

It can be concluded that, if a drought period is forecast, the sinkhole quantity may also be forecast using the equation, and

15 similarly, areas in which quantities of sinkholes are increasing may be considered clear subjects of the impacts of global warming.

\section{Acknowledgements}

This research was supported by the National Natural Science Foundation of China (41302255, 41402284), China Geological Survey Project (1212011220192). We thank Warwick Hastie, PhD, from Liwen Bianji, Edanz Group China

20 (www.liwenbianji.cn/ac), for editing the English text of a draft of this manuscript.

\section{References}

Ahmed M. Youssef., Hasan M. Al-Harbi., Francisco Gutiérrez., Yasser A. Zabramwi., Ali B. Bulkhi., Saeed A. Zahrani., Alaa M. Bahamil., Ahmed J. Zahrani., Zaam A. Otaibi., and Bosy A. El-Haddad.: Natural and human-induced sinkhole hazards in Saudi Arabia: distribution, investigation, causes and impacts. Hydrogeology Journal., 3, 625-644, 2016.

25 Anikeev, A.V., and Leonenko, M.V.: Forecast of sinkhole development caused by changes in hydrodynamic regime: Case study of Dzerzhinsk Karst Area. Water Resources., 7, 819-832, 2014.

Calbó, J., Sánchez-Lorenzo, A., Cunillera, J., and Barrera-Escoda, A.: Projeccions i Escenaris futurs J.E. Llebot (Ed.), 2n Informe sobre el Canvi Climatic a Catalunya, Grup d'Experts en Canvi Climatic de Catalunya. Generalitat de Catalunya i Institut d'Estudis Catalans, Barcelona., 183-239, 2010. 
Nat. Hazards Earth Syst. Sci. Discuss., https://doi.org/10.5194/nhess-2018-18

Manuscript under review for journal Nat. Hazards Earth Syst. Sci.

Discussion started: 30 January 2018

(c) Author(s) 2018. CC BY 4.0 License.
Natural Hazards

and Earth System

Sciences

Discussions

(c) (i)

Coe, J.A., and Godt, J.W.: Review of approaches for assessing the impact of climate change on landslide hazards. In: Eberhardt, E., Froese, C., Turner, A.K., Leroueil, S.(Eds.), Landslides and Engineered Slopes, Protecting Society Through Improved Understanding: Proceedings 11th International and 2nd North American Symposium on Landslides and Engineered Slopes, Banff, Canada 1. Taylor \& Francis Group, London., 371-377, 2012.

5 Floor van den Heuvel., Stéphane Goyette., Kazi Rahman., and Markus Stoffel.: Circulation patterns related to debris-flow triggering in the Zermatt valley in current and future climates. Geomorphology., 272, 127-136, 2016.

Gabriella Szépszó., Imke Lingemann., Bastian Klein., and Mária Kovács.: Impact of climate change on hydrological conditions of Rhine and Upper Danube rivers based on the results of regional climate and hydrological models. Natural Hazards., 1, 241-262, 2014.

10 Gutiérrez, F., Parise, M., De Waele, J., and Jourde, H.: A review on natural and human-induced geohazards and impacts in karst. Earth-Science Reviews., 138, 61-88, 2014.

Han Xiao., Yong Je Kim., Boo Hyun Nam., and Dingbao Wang.: Investigation of the impacts of local-scale hydrogeologic conditions on sinkhole occurrence in East-Central Florida, USA. Enviromental Earth sciences., 75, $1274,2016$.

IPCC, Climate Change.: The Physical Science Basis -Technical Summary (PDF). PP: 89- 90, 2013.

15 Jie Dong., and Xue-feng Jia.: Possible impacts of global climate on natural disasters. Journal of Liaocheng Teachers College(Natural Science Edition) ., 2, 58-62, 2004 (in Chinese).

Mingtang Lei., Yongli Gao., and Xiaozhen Jiang.: Current Status and Strategic Planning of Sinkhole Collapses in China. Engineering Geology for Society and Territory., 5, 529-533, 2015.

Mulec, J., and Prelovšek. M.: Freshwater biodissolution rates of limestone in the temperate climate of the Dinaric karst in

20 Slovenia. Geomorphology., 228, 787-795, 2015.

Seneviratne, S.I., Nicholls, N., Easterling, D., Goodess, C.M., Kanae, S., Kossin, J., Luo, Y., Marengo, J., McInnes, K., Rahimi, M., Reichstein, M., Sorteberg, A., Vera, C., and Zhang, X.: Changes in climate extremes and their impacts on the natural physical environment. In: Field, C.B., Barros, V., Stocker, T.F., Qin, D., Dokken, D.J., Ebi, K.L., Mastrandrea, M.D., Mach, K.J., Plattner, G.-K., Allen, S.K., Tignor, M., Midgley, P.M. (Eds.), Managing the Risks of Extreme Events and

25 Disasters to Advance Climate Change Adaptation. A Special Report of Working Groups I and II of the Intergovernmental Panel on Climate Change (IPCC). Cambridge University Press, Cambridge, UK, and New York, NY, USA., 109-230, 2012.

Stefano Luigi Gariano., and Fausto Guzzetti.: Landslides in a changing climate. Earth-Science Reviews., 162, 227-252, 2016.

Thea Turkington., Alexandre Remaître., Janneke Ettema., Haydar Hussin., and Cees van Westen.: Assessing debris flow 30 activity in a changing climate. Climatic Change., 137, 293-305, 2016.

Wenxin Shi., Shuo Wang., and Qianqian Yang.: Climate change and global warming. Reviews in Environmental Science and Bio/Technology., 2, 99-102, 2010.

Yongming Lin., Haojun Deng., Kun Du., Loretta Rafay., Guangshuai Zhang., Jian Li., Can Chen., Chengzhen Wu., Han Lin., Wei Yu., Hailan Fan., and Yonggang Ge.: Combined effects of climate, restoration measures and slope position in change in 
Nat. Hazards Earth Syst. Sci. Discuss., https://doi.org/10.5194/nhess-2018-18

Manuscript under review for journal Nat. Hazards Earth Syst. Sci.

Discussion started: 30 January 2018

(c) Author(s) 2018. CC BY 4.0 License.

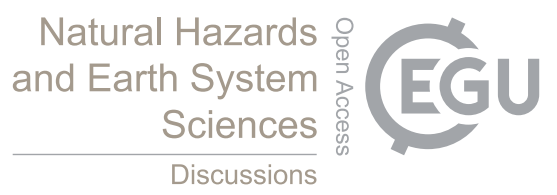

(c) (i)

soil chemical properties and nutrient loss across lands affected by the Wenchuan Earthquake in China. Science of The Total Environment ., 596, 274-283, 2017.

Zhou, Y.F., Tham, L.G., Yan, R.W.M., and Xu. L.: The mechanism of soil failures along cracks subjected to water infiltration. Computers and Geotechnics., 55, 330-341, 2014. 